\title{
Women Were Created with the Exact Same Spiritual and Intellectual Capacity as Men, So of Course They Can Lead
}

\section{QuR'Anic Verses on Women's Spirit and InTEllect}

It is hard not to cringe at having to state the obvious, especially when the opposite suggestion is so downright offensive and plain wrong, both factually and morally. But what can one do?

If the Qur'an tells us as we've seen in the verses discussed in Chap. 5 that all men and women were essentially created from Adam's soul, and that Adam's soul contained no less than the divine breath because God breathed into Adam of His Spirit when giving him life, then surely any differences between human beings spiritually and intellectually can only come from personal differences-never from one's gender, or race for that matter. These personal differences may stem from our individual characteristics or from our environments, but they cannot-by definition-stem from our God-given existence! So how can anyone say that women cannot or must not serve as religious leaders or imams or judges or heads of state? If women can lead, why can't they?

There is no justification whatsoever on a Qur'anic basis for preventing women from fulfilling their potential or any of these roles, with a large number of verses addressing men and women making it clear that both bear equal responsibility for making their societies flourish. This is so evident in the Qur'an that for me to show it in this particular chapter of the book would require re-presenting a large number of the verses I already include in other sections - in particular, see the verses cited in Chap. 11 in the section entitled "Participation".

L. El-Ali, No Truth Without Beauty, Sustainable Development

Goals Series, https://doi.org/10.1007/978-3-030-83582-8_8 
But I will say this, to demonstrate the point: one of the most remarkable discoveries for me personally was to learn quite how responsive God was being at the time, via the Qur'anic verses, to sometimes very personal concerns. I had imagined the Qur'an as being driven solely by big-picture concerns, placing vision for the new religion and community above individual interests at all times. But I was wrong, and as I read on, I came to realise that on occasion, verses were revealed in response to a specific individual's concerns or predicament-in several instances a particular woman's predicament, as we shall see later, on such varied issues as unjust divorce, the right to earn, not being heard, and sexual slander-clearly issues God was signalling He took very seriously. Qur'anic studies indeed place great emphasis on the "reasons for a revelation" (asbab al-nuzul), whatever they may have been. But my favourite story and the one which is relevant here has to be the following.

It appears that some women had raised a concern to the Prophet that the Qur'anic verses being revealed always addressed people in the generic plural form, ${ }^{1}$ which is linguistically masculine in Arabic just as it is in French and Spanish and possibly hundreds of other languages. A noun in Arabic, and in fact a verb also, when referring to a group of women is readily distinguishable from when it refers to a group of men, but when the group is mixed-gender it is the masculine plural that is used. I get goosebumps as I recall the impact this report ${ }^{2}$ first had and still has on me, because God's response was the metaphorical equivalent of Him getting off His throne and taking ten steps towards these women who cared enough to ask, a response which came in the following verse:

The Confederates, 33:35

For submitting men (to God) and submitting women, believing men and believing women, devout men and devout women, truthful men and truthful women, patient men and patient women, humble men and humble women, charitable men and charitable women, fasting men and fasting women, chaste men and chaste women, men who remember God often and women who remember God often-for them God has prepared forgiveness, and a great reward.

Nor was the above the only Qur'anic verse to go to such lengths, as I hope the reader will notice from other verses cited in this book and, of course, when and if they next read the Qur'an.

${ }^{1}$ Abou El Fadl, Khaled M. 2003. Speaking in God's Name: Islamic Law, Authority and Women. Oxford: Oneworld Publications, 230.

${ }^{2}$ Ibid., 255. 
Objectors to women's leadership usually push back against women's advancement primarily by citing supposed hadith denouncing women as such, most strikingly such alleged hadith that re-define women first and foremost as a constant source of sexual enticement and so a moral danger to a presumably otherwise innocent society of men, thereby requiring them to be kept out of sight. And then to prop up their position, objectors point to allegedly Qur'anic obstacles to women's leadership via a combined extrapolation of (a) what the Qur'an meant by bijab (it meant curtain or screen) and (b) how the Qur'an regarded the Prophet's wives (unlike all other women) to arrive at broad gender segregation. The baselessness of these claims laid at the door of the Qur'an, and which are used to limit women's full participation, will be covered in Part IV.

\section{The Pushback of Alleged hadith on Women as Heads of State: But Women Are "Losers"!}

In light of women's natural spiritual and intellectual capacity according to the Qur'an and our own experience of the world, if someone cites a hadith where the Prophet supposedly said that no nation or community would succeed if it had a woman as its leader, what should our reaction be? To me, even if the transmission chain of this hadith was deemed reliable (though scholars have highlighted that this hadith's chief source was a recognised slanderer and rabid woman-hater from the caliph Omar's time) $)^{3}$ and no matter which compilation it appeared in (it was even in Bukhari's), it makes no sense as (a) it contradicts the Qur'anic message of the essential sameness of the two sexes and (b) it represents a generalisation that flies in the face of historical and contemporary evidence in many countries and cultures. But I am most likely to respond with the more potent reminder that if this were truly the case, then God would surely not have devoted a block of two dozen or so verses to telling the story of the powerful Queen of Sheba's wise leadership as she interacted with her court as well as with King Solomon, whom she voluntarily joins in submission to God because, as the Qur'an puts it, she chose the right path $(27: 22-44)$. And if I were in a cheeky mood, I might point to the dozens of countries in the world-starting with Muslim-majority

\footnotetext{
${ }^{3}$ Ibid., 111-113 and Stowasser, Barbara Freyer. 1994. Women in the Qur'an, Traditions, and Interpretation. New York: Oxford University Press Inc., 65-66.
} 
ones-that are led by men but are doing miserably on virtually every indicator of both worldly and spiritual success possible.

The impact of this strange myth cannot be underestimated. While working with a group of civil society activists recently in North Africa, the question of women as heads of state came up. All the men in the group were against the idea as were most of the women in fact, though some of the women as well as men stated that their reason was that a woman president would not succeed at her job given the culture of their countries. But one man offered a different argument that a few others agreed with: Even in America, he said, people say that the American Ambassador to Libya, the late Chris Stevens, would not have died if Hillary Clinton had not been the Secretary of State at the time. No mention was made of this egregious hadith allegedly saying that no nation shall succeed with a woman at its helm, but the illogic of this reasoning leaves me in no doubt that this is the only place the man in question could have been coming from.

If this supposed hadith on the certain disaster that would befall a people who choose a woman as their leader is not a complete fabrication, how might we explain its existence in light of its Qur'anic opposite, as conveyed by the story of the Queen of Sheba, and by Qur'anic gender principles in the holy book?

Perhaps the historic context of this hadith can shed some light:

...this Hadith was narrated from the Prophet by a Companion who recalled that, "When it reached the Prophet that the Persians had placed the daughter of [their former king] Chosroes on the throne, he said, 'A country that entrusts its affairs to a woman will not flourish. ${ }^{4}$

To my mind, the fact that this hadith was a response to a particular development and was not an out-of-the-blue declaration makes all the difference, and causes me to sigh in relief. As believers, we err not only when we take a general principle and then try to clip its wings so as to restrict it to what is convenient for us, but we also err when we do the opposite: when we take the specific and try to extend it into a general principle. In fact, the version of this hadith narrated by Bukhari indicates that the Prophet was simply predicting the fall of Persia, and moreover not all the compilers classified this hadith under their "governance" section,

\footnotetext{
${ }^{4}$ Brown, Jonathan. 2015. Misquoting Muhammad: The Challenge and Choices of Interpreting the Prophet's Legacy. London: Oneworld Publications, 138.
} 


\section{which clearly shows that they did not think it had anything to do with who could or could not become a ruler. ${ }^{5}$}

But I will let the words of a great Islamic jurist and scholar speak for themselves in conclusive commentary on this bizarre hadith:

...it is possible that Abu Bakrah [the narrator of this hadith] was, in fact, someone who saw little value in women ${ }^{6}$. If that is the case, is it possible that the Prophet had commented on the developing situation in Persia by saying, 'A people who are led by this woman will not succeed?' Is it possible that Abu Bakrah misheard the statement because he was receiving it through his own subjectivities? But if the Prophet did make a statement such as the one reported by Abu Bakrah, why was he the only one who seems to have heard it? If, as in some versions, the Prophet made this statement in the presence of Aishah [the Prophet's wife and prolific hadith narrator], why did she not report it? ${ }^{7}$

\section{The Pushback of Ir-rationalisation on Women AS IMAMS: GRASPING AT STRAWS}

The question of women as congregational prayer leaders, or imams, warrants some attention as it has been firmly held almost everywhere in modern times that this is a role that is off-limits to women no matter what. This is despite the opinion of the likes of Tabari, the widely respected tenth-century hadith-based Qur'anic commentator, as well as historical evidence that suggests it is perfectly acceptable, as we shall see below. Justifications for this objection are sometimes anchored in the alleged "women leaders bring failure" hadith and/or by pedantic, puritan and even physiological arguments for good measure.

- The pedantic objection to women leading the prayers goes like this: since women used to line up in rows behind the men's rows during congregational prayers, and not alongside the men, then it must

${ }^{5}$ Abou El Fadl, Khaled. Op. Cit. (2003), 136.

${ }^{6}$ The narrator of this bizarre hadith on women as leaders, Abu Bakrah, is reported to have said: 'The death of a father breaks the back, the death of a son splits the heart, the death of a brother severs the wings and the death of a woman deserves no more than one hour of grief." See Abou El Fadl, Khaled. Op. Cit. (2003), 113.

${ }^{7}$ Abou El Fadl, Khaled. Op. Cit. (2003), 113-114. 
mean that a woman is not supposed to ever be in front of a man. ${ }^{8}$ This argument conveniently omits mention of the fact that during the Prophet's time, when some men arrived late to the congregational prayers they would simply line up in rows behind the women's rows and proceed to join in the rites. ${ }^{9}$ Notice that there was no mention of separate, curtained-off or walled-up areas called the "women's sections" in those days, as has become depressingly widespread throughout the Muslim world today.

- The puritan objection to women leading the prayers maintains that men could not possibly focus and social strife would arise if they had a woman standing in front of them-or worse, if they could hear her voice reciting the prayers or giving the Friday sermon-since women are allegedly a constant source of sexual enticement, apparently even when they are immersed in the worship of God. Notice that the framing of the issue exonerates men from responsibility for their possible actions, placing it squarely on women's shoulders and, some would argue, their implied ever-present ill-intent.

- The physiological objection to women leading the prayers argues that since women cannot perform the prayer or fasting rites during menstruation-according to custom, not the Qur'an-then they cannot act as prayer leaders at any time. The illogic of this argument is glaringly obvious. Some conveniently extend this custom to maintain that women must not utter God's verses either during this time, a significant chunk of a woman's life, nor touch the holy book. Yet the Qur'an mentions menstruation only to say that sexual intercourse should be avoided during that time as it is a "hurt" $(2: 222){ }^{10}$ and the Prophet is known to have asked his wife Aisha to fetch his prayer mat from the mosque during her menstrual period, correcting her when she resisted by saying "Your menstruation is not in your hand!" "In fact two of Muhammad's widows, Aisha and Umm

${ }^{8}$ Brown, Jonathan. Op. Cit. (2015), 38.

${ }^{9}$ Abou El Fadl, Khaled. Op. Cit. (2003), 242.

${ }^{10}$ Some have taken the reference to menstruation as "a hurt" in 2:222 to refer to the discomfort it is known to cause women, but most have taken it to mean "uncleanness", probably influenced by pre-Islamic Arab customs. For more, see Nasr, Seyyed Hossein (editor-in-chief) et al. 2015. The Study Quran: A New Translation and Commentary. New York: HarperCollins Publishers, 97.

${ }^{11}$ le Gai Eaton, Charles. 2008. Chapter: "Purification" in The Book of Hadith: Sayings of the Prophet Muhammad, from the Mishkat al-Masabih. Watsonville, California; Bristol, England: The Book Foundation. 
Salama, openly challenged one Companion's particularly insulting alleged hadiths on menstruation, telling him that they would often be lying in front of the Prophet or pass in front of him during their menstrual period while he was performing his prayers without issue, and numerous reports tell us that the Prophet urged menstruating women to join Eid celebrations at the mosque while others record that women attended prayers there even during menstruation. ${ }^{12}$

\section{Historical Evidence and Medieval Jurist Support FOR WOMEN AS LEADERS}

All of these excuses aimed at preventing women from serving as imams ignore not only the absence of a Qur'anic restriction and the existence of some heavy-weight support for women imams from early and medieval scholars, but also the historical evidence from the Prophet's own time and earliest days of Islam, as recorded in multiple hadiths and later reports.

- The Prophet himself in the seventh century had appointed a woman, Umm Waraqa, as an imam in Medina, and even assigned her a muezzin.

- To those who have argued that Umm Waraqa was instructed to lead the prayers only for members of her household, which consisted of herself and just two servants, one might respond by asking why would the Prophet have then bothered to assign her an old man as muezzin i.e. to perform the call to prayer that summons worshippers who are further afield. ${ }^{13}$

- To those who have argued that Umm Waraqa was tasked with leading a women-only congregation in Medina, one might point out that according to the eighth-century scholar who is the source of this hadith, another five transmitters conveyed the same hadith without mention of a gender restriction ${ }^{14}$.

${ }^{12}$ Abou El Fadl, Khaled. Op. Cit. (2003), 226 and 242.

${ }^{13}$ Reda, Nevin. 2005. Women Leading Congregational Prayers. Canadian Council of Muslim Women paper, 5 and Brown, Jonathan. Op. Cit. (2015), 194.

${ }^{14}$ Brown, Jonathan. Op. Cit. (2015), 194. 
- After the Prophet's death and during the Umayyad caliphate (661-750), a female warrior named Ghazala led her male fighters in prayer at the Kufa mosque they had just taken over. ${ }^{15}$

Such a report, of a woman named Ghazala leading men in prayer so long ago, is not the kind we tend to hear about, any more than we hear about a woman warrior, Nusayba, who fought alongside the Prophet himself and of whom he is reported to have said:

I did not turn right or left on the day of [the battle of] Uhud but saw her there fighting in my place. ${ }^{16}$

Umm Waraqa, who had originally asked the Prophet to join him in battle before he assigned her the role of imam instead, and Ghazala leading her men in prayers in Kufa (in today's Iraq) are not the only examples of women in leadership roles in the religious, political, literary and social spheres of early Islam. Nor was Nusayba the only example of a woman in combat from early Islam: there are reports of Umm Fadl, wife of the Prophet's uncle, attacking and ultimately causing the death of a leading enemy of Islam with a wooden post when she came to the aid of a Muslim slave he was beating, ${ }^{17}$ and of Asma bint Yazid dispatching nine Byzantine enemy soldiers with nothing but her tent pole. ${ }^{18}$

In the religious as well as political realm, the leadership of Aisha, wife of the Prophet, can hardly be overstated. She is the fourth-largest source of hadiths $(2,210$ reports) however they may have been categorised, and:

During her lifetime, she (Aisha) was also honoured for her expertise in medicine and Islamic law. Regarding the hadith, she had not only learnt a large volume of these from her husband, she also showed a critical appreciation of them, and corrected mistakes in understanding of many Companions [of

${ }^{15}$ Abou El Fadl, Khaled. Op. Cit. (2003), 230.

${ }^{16}$ Kahf, Mohja. 2000. Braiding the Stories: Women's Eloquence in the Early Islamic Era. In Windows of Faith: Muslim Women Scholar-Activists in North America, ed. Gisela Webb, 148. New York: Syracuse University Press.

${ }^{17}$ Lings, Martin. 1988. Muhammad: His Life based on the Earliest Sources. London: Unwin Hyman Limited, 153.

${ }^{18}$ Brown, Jonathan. Op. Cit. (2015), 198. 
the Prophet]...even the most important Companions sought her advice on legal problems. ${ }^{19}$

Aisha's co-leadership of an armed uprising following the death of the caliph Omar, whether one sympathises with that rebellion or not, would surely have been impossible if the woman who was the Prophet's beloved and known to be so close to him had ever been told by her husband that God wanted women confined to their homes and playing no part in leading society.

In the religious realm, women as leading Islamic scholars and teachers of mixed-gender audiences flourished in significant numbers until the sixteenth century, as already discussed in Part I, when their numbers began to dwindle noticeably, likely due to multiple external pressures. Their names, those of their notable students, their own teachers and anecdotes from their lives, alongside their male peers', are documented in volume upon volume that form a part of the Islamic religious heritage. ${ }^{20}$ Interestingly, it is known that in the first century of Islam, for example, the following four of the Prophet's wives and two of his female Companions became prominent religious teachers:

- Aisha taught 232 men and 67 women;

- Umm Salama (Hind) taught 78 men and 23 women;

- Umm Habiba (Ramla) taught 18 men and 2 women;

- Hafsa taught 17 men and 3 women.

- Asma bint Abu Bakr taught 19 men and 2 women;

- Asma bint Umays taught 11 men and 2 women. ${ }^{21}$

In fact, the oldest continuously operating institution of higher learning in the world, the University of Qarawiyyin in Fez, Morocco, was founded in the year 859 by a woman, Fatima al-Fihri. ${ }^{22}$

In the literary realm, too, women appear as admired personalities, right from the beginning of Islam, of that highest form of Arabic literature: poetry. "Early Islamic literature" i.e. of the first 40 years of the

\footnotetext{
${ }^{19}$ Siddiqi, Muhammad Zubayr. 1993. Hadith Literature: Its Origin, Development and Special Features. Cambridge, England: The Islamic Texts Society, 21.

${ }^{20}$ Ibid., Appendix I.

${ }^{21}$ Abou El Fadl, Khaled M. 2006. The Search for Beauty in Islam: A Conference of the Books. Maryland: Rowman \& Littlefield Publishers, Inc., 292.

${ }^{22}$ The Economist. 2020. Bygone Civilisations: Secret gardens. February 1.
} 
new religion, from the Prophet's migration to Medina in the year 622 up to the first four caliphs who succeeded him, includes the Qur'an, hadith, sermons by the Prophet and others, and poetry, with one female poet named Khansa included..$^{23}$ And several major literary works after that time point to the influence of women as poets: the renowned anthology of poetry Hamasa, from the ninth century, contains some poems by women; The Eloquence of Women, also from the ninth century, is an anthology of women's contributions in poetry as well as religion and history; The Poetry of Women from the tenth century is a collection of poems by women; and an anthology of poetry by women in the fifteenth century declares that it skips over the early Islamic periods because there is too much poetry by women from those times to cover, choosing to focus on the "modern age" only. ${ }^{24}$

Even in the commercial realm, the fact that Omar, who became caliph just two years after the Prophet's death, appointed a literate woman named Layla (also known as Al-Shifa' i.e. The Cure) as minister of trade and commerce, effectively, in charge of running the souks or commercial marketplaces, speaks volumes. ${ }^{25}$

And in the social realm, likewise, women were never invisible during those first ten centuries or so of Islam in particular, as so many historical documents attest-Hollywood depictions and current Muslim imagination to the contrary notwithstanding. But everyone's favourite story in this regard is the following: when the second caliph, Omar, tried to place a cap on the pre-marital gift the Qur'an had made obligatory for a man to offer his prospective wife for her personal use, a woman interrupted Omar while he was addressing the congregation from the pulpit (yes, she and other women were present in the mosque and not cordoned off out of sight), challenging his premise for doing so and after a debate, Omar conceded his error and backed off. ${ }^{26}$

In terms of Muslim women-rulers overall:

${ }^{23}$ Kahf, Mohja. Op. Cit., 149.

${ }^{24}$ Ibid., 151-52.

${ }^{25} \mathrm{Al}$-Baleek, Imad. 2017. Meet the First Female Minister of Commerce in Islam (in Arabic). Al Arabiya news website www.alarabiya.net, October 19.

${ }^{26}$ al-Hibri, Azizah. 2000. An Introduction to Muslim Women's Rights. In Windows of Faith: Muslim Women Scholar-Activists in North America, ed. Gisela Webb, 59. New York: Syracuse University Press and Brown, Jonathan. Op. Cit. (2015), 198. 
The best-known women rulers in the premodern era include Khayzuran, who governed the Muslim Empire under three Abbasid caliphs in the eighth century; Malika Asma bint Shihab al-Sulayhiyya and Malika Arwa bint Ahmad al-Sulayhiyya, who both held power in Yemen in the eleventh century; Sitt al-Mulk, a Fatimid queen of Egypt in the eleventh century; the Berber queen Zaynab al-Nafzawiyah (r. 1061-1107); two thirteenthcentury Mamluk queens, Shajar al-Durr in Cairo and Radiyyah in Delhi; six Mongol queens, including Kutlugh Khatun (thirteenth century) and her daughter Padishah Khatun of the Kutlugh-Khanid dynasty; the fifteenthcentury Andalusian queen Aishah al-Hurra, known by the Spaniards as Sultana Madre de Boabdil; Sayyida al-Hurra, governor of Tetouán in $\operatorname{Morocco}$ (r. 1510-1542); and four seventeenth-century Indonesian queens. ${ }^{27}$

Such reports depicting women as leaders in various spheres are part of our heritage, and it is time for us to reclaim them. It is time to push back against those minority but loud voices that would claim that a woman's very voice must not be heard, that it is something to be hidden away just as surely as her private parts are. Outrageous as this claim is, it exists in some corners of "modern" Islam: it was in fact in a BBC report just today, the 3rd of December, 2017 as I write, on conflicting views about a newly pious Middle Eastern female singer's decision to re-embrace her music, after a hiatus, by channelling it into devotional songs. Such a claim not only exists but passes itself along by asserting that God himself considers a woman's voice a 'awra: at best, a private part to be hidden from detection and at worst, a flaw or defect. Give me medieval Islam any day, thank you!

In any case I was pleased to learn that despite the alleged hadith on women as inappropriate heads of state, not all early interpreters had extended its questionable political application to also argue that women should never become judges or religious leaders eitherincluding prayer leaders (imams):

- Many jurists of the Maliki school (there are 4 schools of jurisprudence in Sunni Islam) argued that women could become judges without restrictions ${ }^{28}$

${ }^{27}$ Oxford Islamic Studies Online. Women and Islam. Oxford University Press. www. oxfordislamicstudies.com/article/opr/t125/e2510\#. Accessed November 2019.

${ }^{28}$ Abou El Fadl, Khaled. Op. Cit. (2003), 111. 
- The founder of the Hanafi school of jurisprudence, Abu Hanifa (d. 767), thought that women could serve as judges in commercial and civil cases but not in criminal and personal injury ones ${ }^{29}$

- The hugely respected Qur'anic commentator Tabari (d. 923) not only maintained that women could become judges without restrictions, but that women could also lead men in the communal prayers ${ }^{30}$

- Two leading students of the founder of the Shafi'i school in the ninth century had allowed women to lead the prayers ${ }^{31}$

- The towering Ibn Arabi (d. 1240), who was a formidable jurist and hadith scholar and not only a great Sufi master, unequivocally affirmed women's right to lead the communal prayers by pointing to the absence of Qur'anic or even hadith proof to support the objection, citing women's roles as spiritual leaders and bearers of prophecy in history, and concluded that those who argue otherwise "should not be listened to" 32

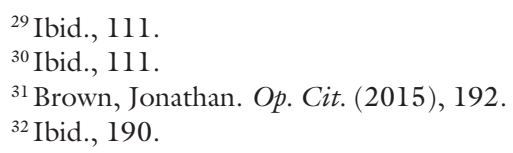

Open Access This chapter is licensed under the terms of the Creative Commons Attribution 4.0 International License (http://creativecommons.org/licenses/ by $/ 4.0 /$ ), which permits use, sharing, adaptation, distribution and reproduction in any medium or format, as long as you give appropriate credit to the original author(s) and the source, provide a link to the Creative Commons licence and indicate if changes were made.

The images or other third party material in this chapter are included in the chapter's Creative Commons licence, unless indicated otherwise in a credit line to the material. If material is not included in the chapter's Creative Commons licence and your intended use is not permitted by statutory regulation or exceeds the permitted use, you will need to obtain permission directly from the copyright holder.

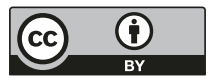

